of a duplex system in which the relative development of lipoidal and idiosomic substances may undergo considerable variation.

Having established a probability in favour of the essential homology between secretory granules and the acrosome of the animal sperm, Dr. Bowen suggests that the relationship between the Golgi apparatus and the secretory granules is homologous to that existing between the Golgi apparatus and the acrosome, and that our more complete understanding of the latter phenomenon can be used as a basis for interpreting the much more obscure phenomena in the gland cell. He adds that the establishment of the views developed in his paper must depend finally upon further critical evidence from favourable material bearing upon the exact relation which exists between the individual secretory granule and the Golgi complex.

Dr. Bowen holds that no cytological evidence of the origin of secretory products from the nucleus receives any acceptance at the present time. The nucleus can be considered as the source of secretions only in the indirect sense that it may possibly exercise some control over the process as a whole, or may collaborate with other parts of the cell-system in preparing materials for the synthetic operations of the Golgi apparatus.
When a cell is divided into a nucleated and a nonnucleated portion, the latter is able to carry on synthetic activities for a brief period only; meanwhile the nucleated part regenerates and appears none the worse for the operation. Hence it was concluded that the nucleus is the centre of synthetic operations, and particularly of the formation of those intracellular enzymes upon which living activity is now supposed to depend. But it is at least equally possible that the nucleated piece alone continues capable of constructive metabolism because it possesses the complete cell-system, while in the non-nucleated piece the system is disrupted. Dr. Bowen remarks that if the Golgi apparatus could be eliminated, the cell would doubtless be fatally affected. While secretion is an activity in which the cell-system as a whole is probably involved, and over which the nucleus exercises some controlling influence, the actual synthetic centre for the differentiation of secretory granules is the Golgi apparatus. That this source of the visible secretory granules " is likewise the source of the invisible, intra-cellular enzymes . . . cannot at present be doubted, but our scanty knowledge of these things makes any hypothesis whatever almost pure speculation."

\title{
Forestry in Illinois and Great Britain.
}

$\mathrm{I}^{\mathrm{T}}$ is common knowledge that the drain upon the world's resources of coniferous timber is very heavy, and that in some countries the outlook is regarded with increasing disquietude. In the "Third Report on a Forest Survey of Illinois," by C. J. Telford, the position of the State is explained with great clarity, and the parallel to the state of affairs existing in Great Britain is depicted. The present forests of the United States contain an estimated total of $48 \mathrm{I}, 800$ million cubic feet of standing timber, the annual cut is 25,000 million cubic feet and the annual growth 6039 million cubic feet. " The virgin forests," the report says, "will carry us another 25 years, after which we shall probably be wholly dependent upon growth from cut-over lands. By utilising the entire 470 million acres of forest lands at prevailing rates of growth these cut-over lands can supply us with an estimated annual yield of $I_{4}, 000$ million cubic feet-a little more than half our present requirements. The conviction that satisfactory substitutes for wood will be found is untenable when the enormous amount of wood required is appreciated. This drain of 25,000 million cubic feet of standing timber a year means that for every hundred pounds of coal, iron, cement, petroleum and copper consumed the forests supply 67 pounds of wood, and the crop lands supply 44 pounds of all forms of crops, including cereals, seeds, clover, hay, forage, cotton, potatoes, sugar, fruit, and nuts. It is obvious that a satisfactory substitution for a commodity representing by weight two-thirds of virtually all the minerals consumed, or one and a half times all crops raised in the United States, is impossible. A timber famine will be more disastrous to Illinois than to any other State. Its manufacturing establishments employ $\mathrm{I} \times \cdot 6$ per cent. more hands than agriculture, transportation, and mining combined, and thirty per cent. of all persons employed in manufacture are in industries dependent upon wood. In the single item of lumber, Illinois consumes one-thirtieth the total lumber-cut of the world."

The process of forest destruction is far advanced in Illinois. Virgin timber has practically disappeared, and the present drain on the cut-over forests and second growth stands, unchecked, will, it is held, result in an early disappearance of all forests in the State. There was an increase in unforested waste land of 250,000 acres in the ten years from roro to I920, and Illinois now has a total of $\mathbf{I}, 577,663$ acres in this class. The $3,021,650$ acres now forested are on lands unsuited to ordinary farming, and if cleared will generally revert to waste land. The state of affairs thus briefly delineated is sufficiently alarming from the industrial outlook alone and renders the more interesting the following comparison with the position of Great Britain.

"There is a striking parallel between Illinois and Great Britain in the total wood consumption and in the total area forested. Each annually consumes approximately the same quantity of wood $-560,720,000$ cubic feet for Illinois and $600,000,000$ cubic feet for Great Britain ; each has about the same area forested $-3,02 \mathrm{I}, 650$ for Illinois and about 3,000,000 acres for Great Britain. But Great Britain, despite a population of 437.5 to the square mile as compared with I 5.7 in Illinois, and the consequent pressure for land, has deliberately undertaken to replant $x, 770,000$ acres, and this planting is being done at the rate of 20,000 acres a year. Illinois has never planted 200 acres of publicly owned forests, her farm woodlands are decreasing at the rate of 4500 acres a year, and the unimproved and waste land on farms is increasing at the rate of 25,000 acres a year."

\section{Bird Flight.}

IN the Transactions of the Royal Society of South Australia, vol. i., I926, an interesting contribution is made by Prof. F. Wood Jones on the flight of sea-birds. It has long been observed that many sea-birds spend protracted periods, sometimes soaring, sometimes gliding, and at any rate to the novice, apparently without a visible tremor of the wing. Their flight appears to be merely an ability to slide ahead with no other power than their own weight and a presumably instantaneous ability to readjust their planes and alter their cant and poise apparently largely by movements of the head.

As a result of close study and observation extending over many years, Hankin maintains that in the

$$
\text { NO. } 298_{3} \text {, VOL. I I9] }
$$


wake of a ship the air must possess a physical property which he terms soarability' by means of which seabirds are enabled to extract from the air in that region an upward momentum. Presumably this must mean that the air in passing over the ship is set into a state of disturbed eddying of such a general direction of rotation and of such a distribution of intensity vertically that the bird experiences a lift it would not otherwise acquire.

Prof. Wood Jones, on the other hand, regards the soaring and gliding of pelagic birds as due rather to a morphological adaptation of the bird as an adjusted plane than to any chance condition of "soarable" air. Regarded in this way, he maintains, the zoned north and south distribution of the different morphological types of sea-birds and the failure of the albatross, for example, to follow ships into the tropics, well adapted as it is for gliding, must be investigated from the point of view of bird structure correlated to the environment to which it appears to be adapted. In the case of the albatross, there appears to be a perfect mastery of aerial conditions well to the south of the equator, a lessening mastery farther north, and a positive disability, laboured flapping flight, as the journey is made towards the equator. The same facts apparently hold with regard to the northern representatives.

Prof. Wood Jones points out, moreover, that the zonal distribution of species from the equator northwards is very similar to the distribution southwards from the equator, with a similar increasing ratio of weight to wing area, culminating at both poles with the southern penguins at one end and their extraordinary parallels, the northern auks, at the other. The clue to this gradation is to be sought in the increase in atmospheric density from the equator in both directions, so that a bird adapted for flight in the denser atmosphere finds difficulty in maintaining its gliding and soaring in the rarer atmospheres of the tropics. By indicating this new line of approach, Prof. Wood Jones undoubtedly has given a new impetus to the study of bird flight.

\section{University and Educational Intelligence.}

Birmingham.-Mr. H. Munro Fox, fellow of Gonville and Caius College, Cambridge, has been appointed to the Mason chair of zoology to succeed the late Prof. F. W. Gamble. Mr. C. G. C. Chesters has been appointed assistant lecturer in botany.

The Council has recommended to the Court of Governors that the title of emeritus professor be conferred on Thomas Turner, formerly professor of metallurgy.

EDINBURGH.-At the graduation ceremony on December 17, the degree of D.Sc. was conferred on Baini Prashad, Superintendent of the Zoological Survey of India, the Indian Museum, Calcutta, for his thesis on (1) "Recent and Fossil Viviparidæ : a Study in Distribution, Evolution, and Palæogeography," and (2) "The Shell and Mantle of the Viviparidæ"; the degree of Ph.D. on R. K. S. Mitchell for his thesis on "Some $\beta$ Octyl Esters of Substituted Acetic Acid" ; and the degree of M.D. on Eric H. Ponder, with gold medal, for his thesis on "Studies in Hæmatology."

Applicatrons are invited by Yale University for two Theresa Seessel Research Fellowships for the promotion of original research in biological studies. The value of each is 1500 dollars. Preference will be given to candidates who have already obtained their doctorate, and have demonstrated by their work fitness to carry on successfully original research of a high order. The holder must reside in New Haven during the college year, October to June. Applications, accompanied by reprints of scientific publications, letters of recommendation, and a statement of the particular problem which the candidate expects to investigate, should be made to the Dean of the Graduate School, New Haven, Conn., before March 1, 1927.

IN the course of the past year inquiries were made by the Institution of Mechanical Engineers of the colleges and schools conducting approved part-time courses as to the ages and occupations of candidates for the Ordinary and Higher National Certificates in mechanical engineering. Information has been supplied from 85 colleges and schools in Great Britain in respect of 1000 candidates for the ordinary certificate and $\mathbf{3 3 4}$ for the higher certificate. The average age of the former candidates was about 19.5 years, and of the latter about 21.5 years. No less than 801 of the 1000 candidates for the ordinary certificate were between the ages of 18 and 21 years. Classifying the candidates in respect of occupation, it was found that apprentices of all classes constitute $71 \cdot 3$ per cent. of the candidates for the ordinary certificate, and 32.4 per cent. of those for the higher certificate, and that the combined proportions of trade apprentices and mechanics following these courses are $42 \cdot 4$ per cent. for the ordinary certificate and 37.7 per cent. for the higher certificate. The proportions of successful candidates were $\mathbf{5 2 . 5}$ per cent. for the ordinary certificate and 67 per cent. for the higher certificate.

The East Anglian Institute of Agriculture, Chelmsford, announces in its Calendar for 1926-27 that alterations during 1925-26 have enabled it to offer facilities for instruction of a more advanced character than that obtainable at any similar institute in Great Britain. The research work at present in progress includes deterioration diseases of potatoes, seeds mixtures, autumn versus spring sowings, composition of butter-fat in goat's milk, winter spraying, colonisation of salt marshes, bunt in wheat, wheat bulb $\mathrm{fly}$, and Hessian fly. Agricultural economics courses include one on the history of British agriculture. Special courses on the agriculture of New Zealand, of Australia, and of Canada and South Africa, are provided. A list of appointments held by past students does not indicate that any of them have as yet gone abroad. The North of Scotland College of Agriculture has a very different record in this respect, a very large proportion of the posts held by its former students being in other countries. The Calendar of this College for 1926-27 announces, among other courses, a "Planter's Certificate Course" specially provided to meet the requirements of students intending to enter on service upon tea, coffee, rubber, sugar, and other plantations in tropical and subtropical countries. It extends over two complete winter sessions and one intervening summer session. No preliminary qualifying examination is prescribed. Nine students obtained the degree of B.Sc. in agriculture during the past session. The courses in forestry formerly provided by the College have been transferred to the University of Aberdeen. The Edinburgh and East of Scotland College of Agriculture has in the past, like the North of Scotland College, sent many students abroad, but the list published in its new Calendar of appointments gained by students shows a falling off in this respect. This College, like the East Anglian Institute, offers a course on the history of British agriculture based on Lord Ernle's " English Farming, Past and Present." 